\title{
Tingkat Literasi Keuangan Syariah Pedagang Pasar di Kota Padangsidimpuan
}

\author{
Rizal Ma'ruf Amidy Siregar \\ Institut Agama Islam Negeri Padangsidimpuan \\ Jl. H. Tengku Rizal Nurdin Km. 4.5 Sihitang \\ Kota Padangsidimpuan - Sumatera Utara \\ E-mail : amidy.siregar@gmail.com
}

Diterima: 11 Oktober 2018; Direvisi: 12 Desember 2018; Diterbitkan: 29 Desember 2018

\begin{abstract}
Abstrak,
Kota Padangsidimpuan sebagai salah satu kota di Provinsi Sumatera Utara, merupakan bagian integral dalam memajukan perbankan syariah di Indonesia pada umumnya, dan di Sumatera Utara pada khususnya. Perkembangan perbankan syariah di Padangsidimpuan tidak lepas dari peran pedagang pasar sebagai nasabah bank-bank syariah di Padangsidimpuan, baik sebagai nasabah tabungan maupun nasabah pembiayaan. Pasar terbesar di Padangsidimpuan adalah Sangkumpal Bonang dan sekitarnya, yang merupakan jantung perekonomian kota ini. Penelitian ini bertujuan untuk mengetahui karakteristik tingkat literasi pedagang Pasar Sangkumpal Bonang terhadap produk perbankan syariah . Penelitian ini berfokus pada ada tidaknya perbedaan literasi keuangan pedagang di Pasar Sangkumpal Bonang berdasarkan usia, pendidikan terakhir dan penghasilan rata-rata dengan menggunakan metode analisis deskriptif dan Chi-Square. Penelitian ini membuktikan bahwa semakin tinggi tingkat pendidikan responden (pedagang pasar Sangkumpal Bonang), semakin banyak responden yang paham (literated) akan keuangan syariah. Demikian juga halnya tingkat pendapatan responden, semakin tinggi pendapatan rata-rata per bulan, semakin banyak pula responden yang literated keuangan syariah. Sedangkan berdasarkan tingkat usia, tidak ada perbedaan tingkat literasi keuangan syariah responden.
\end{abstract}

Kata Kunci: Pedagang Pasar, Literasi Keuangan, Syariah, Padangsidimpuan

\section{Abstract,}

Padangsidimpuan city as one of the cities in North Sumatra Province, is an integral part of advancing Islamic banking in Indonesia in general, and in North Sumatra in particular. The development of Islamic banking in Padangsidimpuan cannot be separated from the role of merchant as customers of Islamic banks in Padangsidimpuan, both as saving and financing customers. The biggest market in Padangsidimpuan is Sangkumpal Bonang and its surroundings, which is the center of economic activity of the city. This study aims to find out how the literacy level of Sangkumpal Bonang's merchant to sharia financial products. This study discusses the difference in sharia financial literacy of Sangkumpal Bonang's merchant based on age, the last education and the average incomes per month, using descriptive analysis methods and Chi-Square. This study proves that the higher the level of respondents formal education, the higher their sharia financial literacy rate. Likewise, the respondent's income level, the higher the average income per month, the higher their sharia financial literacy rate. While based on age, there is no difference in the level of respondents' sharia financial literacy.

Keywords: Merchant, Financial Literacy, Sharia, Padangsidimpuan 


\section{PENDAHULUAN}

Literasi keuangan, khususnya produk-produk keuangan yang ditawarkan oleh perbankan merupakan hal yang sangat penting di berbagai tingkatan. Dari perspektif kesejahteraan sosial, jelas sangat penting apakah masyarakat dapat mengelola urusan keuangan mereka secara bijaksana dan hidup sesuai dengan kemampuan mereka. Namun, manfaat "melek" finansial lebih luas daripada hal tersebut, yaitu untuk mewujudkan sistem keuangan yang lebih tangguh dan alokasi sumber daya yang lebih efisien dalam ekonomi riil.

Salah satu isu penting dalam mengembangkan industri perbankan syariah nasional adalah terkait dengan sosialisasi dan edukasi publik. Berdasarkan survey Otoritas Jasa Keuangan (OJK) pada tahun 2013 yang dilaksanakan di 20 provinsi di indonesia, diketahui bahwa tingkat literasi keuangan masyarakat indonesia yang tergolong well literate hanya mencapai angka 21,84 persen. Khusus terhadap perbankan, tingkat literasi juga tidak jauh berbeda, yaitu mencapai angka 21,80 persen. hal ini menunjukan bahwa masyarakat yang memiliki pengetahuan dan keyakinan terhadap lembaga, produk dan jasa perbankan, serta memiliki keterampilan dalam menggunakan produk dan jasa perbankan, hanya seperlima dari total penduduk secara keseluruhan.

Rendahnya tingkat literasi keuangan selaras dengan rendahnya pemanfaatan produk dan jasa perbankan oleh masyarakat yang hanya mencapai 57,28 persen. Edukasi literasi keuangan bagi masyarakat menjadi suatu program strategis OJK dalam meningkatkan penggunaan produk lembaga keuangan, dengan Usaha Mikro, Kecil dan Menengah (UMKM) sebagai prioritas sasaran edukasi literasi keuangan pada tahun 2014.

Indonesia adalah negara Muslim mayoritas terbesar di dunia. Sebagai negara Muslim terbesar harusnya Indonesia bangga dengan hal-hal yang berbau Islam. Indonesia berpotensi menjadi pusat keuangan syariah, jika pemerintah Indonesia serius menjadikan ekonomi syariah sebagai keunikan negara (differentiation). Namun amat disayangkan kebanyakan penduduk di Indonesia belum memiliki kesadaran (awareness) tentang ekonomi, perbankan dan keuangan syariah. Khalid Howladar, Kepala Islamic Finance Moody's, menyatakan bahwa salah satu tantangan terbesar perkembangan keuangan syariah di Indonesia adalah rendahnya kesadaran masyarakat tentang perbankan dan keuangan syariah.

Pentingnya kesadaran masyarakat sebenarnya sudah mulai disadari stakeholders perbankan dan keuangan syariah di tanah air. Otoritas Jasa Keuangan (OJK) misalnya, secara regular mengadakan Forum Riset Keuangan Syariah yang diadakan berkerjasama dengan Ikatan Ahli Ekonomi Islam (IAEI) dan universitas-universitas di Indonesia. 
Program-program tentang ekonomi, perbankan dan keuangan syariah pun mulai marak di televisi dan radio-radio di tanah air. Namun, usaha-usaha peningkatan kesadaran masyarakat masih perlu ditingkatkan lagi. Berdasarkan temuan Sutan Emir Hidayat, masih banyak masyarakat awam yang belum sadar dengan keberadaan ekonomi rabbani di tanah air. Bahkan, sebahagian masyarakat justru mendapat informasi yang keliru, yang menyimpulkan tidak ada bedanya antara ekonomi, perbankan dan keuangan syariah dengan ekonomi, perbankan dan keuangan konvensional.

Terdapat sejumlah alasan mengapa perbankan konvensional yang ada sekarang ini mulai melirik untuk menggunakan dan mengembangkan sistem syariah, diantaranya adalah pasar potensial yang besar, karena mayoritas penduduk Indonesia beragama Islam dan semakin tingginya kesadaran masyarakat muslim untuk berperilaku secara Islami termasuk didalamnya yaitu aspek muamalah atau berniaga. Dalam hal ini masyarakat mendapatkan pilihan kepada sistem keuangan berbasis syariah yang sesuai dengan kebutuhannya. Di samping itu, masyarakat memiliki alternatif lain dalam melakukan aktivitas keuangannya. Hal tersebut memberi dampak akan kebutuhan bank syariah yang semakin tinggi.

Bank syariah hanya membayar bagi hasil kepada nasabahnya sesuai dengan marjin keuntungan yang diperoleh bank, dengan sistem ini bank syariah tidak akan mengalami negative spread. Hal inilah yang menjadi pendorong berkembangnya perbankan syariah di negara-negara yang penduduk muslimnya minoritas. Sebagai contoh, 60\% nasabah Bank Islam di Singapura adalah non muslim. Kalangan perbankan di Eropa pun sudah melirik potensi perbankan syariah. BNP Paribas SA, bank terbesar di Perancis telah membuka layanan syariahnya yang diikuti oleh UBS Group, sebuah kelompok perbankan terbesar di Eropa yang berbasis di Swiss, telah mendirikan anak perusahaan yang diberi nama Noriba Bank yang juga beroperasi penuh dengan sistem syariah. Demikian halnya dengan HSBC dan Chase Manhattan Bank yang juga membuka window syariah.

Penjelasan di atas menunjukkan bahwa banyak negara-negara dengan penduduk beragama Islam merupakan kelompok minoritas - baik di Asia maupun di Eropa - sangat antusias untuk mengembangkan ekonomi syariah, khususnya di bidang perbankan syariah. Oleh karena itu, dalam rangka agar Indonesia tidak kalah dalam persaingan ekonomi syariah global, masyarakat di seluruh pelosok tanah air harus meningkatkan pemahamannya tentang produk-produk perbankan syariah. Sehingga perkembangan perbankan syariah di Indonesia semakin pesat.

Kota Padangsidimpuan sebagai salah satu kota di Provinsi Sumatera Utara, merupakan bagian integral dalam memajukan perbankan syariah di Indonesia pada umumnya, dan di Sumatera Utara pada khususnya. Perkembangan perbankan syariah di 
Padangsidimpuan tidak lepas dari peran masyarakat sebagai nasabah bank-bank syariah di Padangsidimpuan, baik sebagai nasabah tabungan maupun nasabah pembiayaan.

Pasar terbesar di Padangsidimpuan adalah Sangkumpal Bonang dan sekitarnya, yang merupakan jantung perekonomian kota ini. Apabila seluruh pedagang di Pasar Sangkumpal Bonang menabung sebagian keuntungan usahanya di bank syariah, begitu juga ketika membutuhkan modal tambahan, pedagang pasar tersebut mengajukan pembiayaan di bank syariah, maka perkembangan ekonomi syariah di Padangsidimpuan akan semakin maju pesat. Semakin tinggi tingkat literasi pedagang Pasar Sangkumpal Bonang terhadap produk perbankan syariah, maka semakin tinggi pula peluang mereka menabung dan meminjam di bank syariah.

\section{TINJAUAN TEORITIK}

\section{Kategori Tingkat Literasi Keuangan di Indonesia}

Otoritas Jasa Keuangan (OJK) Republik Indonesia merupakan sebuah lembaga Pelaksanaan Edukasi yang memiliki peran dalam meningkatkan keuangan masyarakat. OJK mengkategorikan tingkat literasi keuangan masyarakat Indonesia menjadi empat. Pertama, well literate yaitu memiliki pengetahuan tentang lembaga jasa keuangan serta produk jasa keuangan, memiliki keyakinan terhadap produk keuangan yang dipilih, serta memiliki keterampilan dalam menggunakan produk dan jasa keuangan.

Kedua, sufficient literate yaitu memiliki pengetahuan dan keyakinan tentang lembaga jasa keuangan serta produk dan jasa keuangan, termasuk fitur, manfaat dan risiko, hak dan kewajiban terkait produk dan jasa keuangan.

Ketiga, less literate yaitu hanya memiliki pengetahuan tentang lembaga jasa keuangan, produk dan jasa keuangan.

Keempat, non-literate yaitu benar-benar tidak memiliki pengetahuan dan keyakinan terhadap lembaga jasa keuangan serta produk dan jasa keuangan, serta tidak memiliki keterampilan dalam menggunakan produk dan jasa keuangan.

Literasi Keuangan memiliki tujuan jangka panjang bagi seluruh golongan masyarakat, yaitu: (1) Meningkatkan literasi seseorang yang sebelumnya less literate atau not literate menjadi well literate; dan (2) Meningkatkan jumlah pengguna produk dan layanan jasa keuangan. Masyarakat luas diharapkan dapat menentukan produk dan layanan jasa keuangan yang sesuai dengan kebutuhan. Untuk mencapai hal tersebut, masyarakat harus memahami dengan benar manfaat dan risiko, mengetahui hak dan kewajiban serta meyakini 
bahwa produk dan layanan jasa keuangan yang dipilih dapat meningkatkan kesejahteraan masyarakat.

Bagi masyarakat, Literasi Keuangan memberikan manfaat yang besar, seperti: (1) Mampu memilih dan memanfaatkan produk dan layanan jasa keuangan yang sesuai kebutuhan; (2) memiliki kemampuan dalam melakukan perencanaan keuangan dengan lebih baik; dan (3) Terhindar dari aktivitas investasi pada instrumen keuangan yang tidak jelas. Literasi Keuangan juga memberikan manfaat yang besar bagi sektor jasa keuangan. Lembaga keuangan dan masyarakat saling membutuhkan satu sama lain sehingga semakin tinggi tingkat Literasi Keuangan masyarakat, maka semakin banyak masyarakat yang akan memanfaatkan produk dan layanan jasa keuangan.

\section{Penelitian Terdahulu}

Emmanuel K. Oseifuah mengajukan tiga indikator financial literacy, yaitu: 1) Financial Knowledge: memiliki pengetahuan mengenai terminologi-terminologi keuangan, misalnya tingkat suku bunga bank, kartu kredit, kebangkrutan, pasar saham, bermacammacam layanan jasa perbankan, memahami istilah-istilah, perhitungan-perhitungan dan manfaat perpajakan, tahu berbagai layanan pengelola dana pensiun, serta mengetahui berbagai sumber pendapatan keluarga; 2) Financial attitudes: ketertarikan/ minat dalam memperbaiki pengetahuan keuangan, merencanakan program keuangan pensiun untuk karyawannya, melaksanakan kebijakan pemerintah dalam hal pajak, menggunakan layananlayanan jasa perbankan yang berkaitan dengan luar negeri; dan 3) Financial behavior: berorientasi untuk spending dan saving, mencatat dan menyimpan catatan keuangan pribadinya, dan merencanakan pembiayaan untuk masa depan, mengelola hutang dan kredit dengan tepat sesuai dengan cash flow perusahaan.

Irin Widayani mengembangkan 15 indikator melek finansial disesuaikan dengan kondisi di Indonesia yaitu: 1) mencari pilihan-pilihan dalam berkarir, 2) memahami faktorfaktor yang mempengaruhi gaji bersih, 3) mengenal sumber-sumber pendapatan, 4) menjelaskan bagaimana mencapai kesejahteraan dan memenuhi tujuan keuangan, 5) memahami anggaran menabung, 6) memahami asuransi, 7) menganalisis risiko, pengembalian, dan likuiditas, 8) mengevaluasi alternatif-alternatif investasi, 9) menganalisis pengaruh pajak dan inflasi terhadap hasil investasi, 10) menganalisis keuntungan dan kerugian berhutang, 11) menjelaskan tujuan dari rekam jejak kredit dan mengenal hak-hak debitur, 12) mendeskripsikan cara-cara untuk menghindari atau memperbaiki masalah hutang, 13) mengetahui hukum dasar perlindungan konsumen dalam kredit dan hutang, 14) 
mampu membuat pencatatan keuangan, dan 15) memahami laporan neraca, laba rugi, dan arus kas.

Sementara itu Lusimbo dan Muturi melakukan penelitian Financial Literacy And The Growth Of Small Enterprises In Kenya: A Case Of Kakamega Central Sub-Country, Kenya yang bertujuan untuk mengetahui dampak dari literasi hutang dan pencatatan keuangan terhadap pertumbuhan UMKM. Hal yang melatarbelakangi penelitian ini yakni tingginya angka kelahiran usaha kecil sekaligus tingginya angka kegagalan usaha kecil di Kenya. Penelitian ini menggunakan metode survei dengan melakukan penyebaran kuesioner pada manager usaha kecil di Kenya. Metode pada penelitian ini yaitu dengan menganalisis secara deskriptif melalui persentase dan frekuensi data yang didapatkan. Hasil penelitian menunjukkan bahwa pemilik usaha kecil yang memiliki literasi hutang yang baik belum memahami dampak dari inflasi dan suku bunga pinjaman yang mereka pinjam dan belum dapat membandingkan persyaratan antar produk keuangan sebelum mereka membelinya. Kesimpulan pada penelitian ini yaitu pemilik usaha kecil yang memiliki literasi keuangan rendah berdampak pada minimnya pertumbuhan usaha bahkan menyebabkan usahanya tidak dapat bertumbuh sama sekali.

Penelitian yang dilakukan oleh Shawn Cole, Thomas Sampson, dan Bilal Zia di Indonesia dan India menemukan bahwa pelatihan di bidang literasi keuangan tidak berpengaruh terhadap peluang/ probabilitas membuka rekening tabungan bank, walaupun secara signifikan meningkatkan probabilitas di antara mereka yang memiliki tingkat pengetahuan awal (mengenai jasa perbankan) yang rendah, dan tingkat pendidikan yang rendah. Subsidi keuangan, sebaliknya, memiliki pengaruh yang besar secara signifikan. Subsidi yang dilakukan oleh pemerintah meningkatkan jumlah rumah tangga yang membuka rekening tabungan bank. Subsidi meningkatkan porsi rumah tangga yang membuka rekening tabungan bank dari 3,5\% menjadi 12,7\%, meningkat hampir tiga kali lipat. Oleh karena itu, subsidi atau pengurangan harga merupakan cara yang efektif berbiaya rendah untuk mengajak masyarakat menggunakan jasa-jasa perbankan (konvensional dan syariah). Sebaliknya, upaya melek finansial yang ditargetkan pada masyarakat umum selama ini relatif tidak efektif.

Musyafiq Hasyim dan Abdullah Salam melakukan penelitian yang bertujuan untuk mengetahui pengaruh status pendidikan dan status pekerjaan terhadap pengetahuan produk-produk bank syariah. Responden penelitian ini adalah rumah tangga di Padukuhan/ Krapyak Dukuh Kulon, Sewon, Bantul, Yogyakarta. Populasi dalam penelitian ini sebanyak 917 Kepala Keluarga dan sampel yang diteliti adalah sebanyak 95 responden. Hasil uji t menunjukkan bahwa setiap variabel bebas berpengaruh secara signifikan terhadap 
pengetahuan produk-produk bank syariah. Hasil uji $\mathrm{F}$ juga menunjukkan bahwa kedua variabel bebas berpengaruh secara simultan. Koefisien determinasi penelitian ini adalah sebesar 0,173. Dengan demikian, variasi variabel terikat (pengetahuan produk-produk bank syariah) dapat dijelaskan oleh variasi variabel bebas (status pendidikan dan status pekerjaan) sebesar $17,3 \%$, sedangkan sisanya $82,7 \%$ dijelaskan oleh variabel lain yang tidak termasuk dalam model penelitian.

\section{METODE PENELITIAN}

Jenis penelitian ini merupakan penelitian kuantitatif. Pendekatan penelitian yang digunakan adalah deskriptif analitis, yaitu pendekatan yang bertujuan mengumpulkan data sesuai dengan keadaan yang sebenarnya, menyajikan dan menganalisisnya sehingga dapat memberikan gambaran yang cukup jelas atas objek yang diteliti dan kemudian dapat ditarik kesimpulan. Melalui pendekatan ini, peneliti dapat mendeskripsikan tingkat literasi pedagang pasar Sangkumpal Bonang terhadap produk perbankan syariah.

\section{Teknik Penetapan Responden}

Populasi penelitian ini adalah seluruh pedagang yang berlokasi di Pasar Sangkumpal Bonang pada saat penelitian dilakukan. Berdasarkan hasil wawancara Focus Group Discussion (FGD) dengan Kepala Bidang Perdagangan Dinas Perdagangan Kota Padangsidimpuan, jumlah pedagang di Pasar Sangkumpal Bonang adalah sejumlah 482 orang.

Pemilihan sampel penelitian ini ditentukan secara Purposive Sampling dengan tujuan untuk mendapatkan sampel yang representif sesuai dengan kriteria yang ditentukan. Kriteria responden dalam penelitian ini adalah: (1) pedagang yang memiliki rencana untuk menabung atau meminjam di bank syaraiah; atau (2) pedagang yang memiliki akun di bank konvensional dan atau bank syariah. Jumlah responden dalam penelitian ini adalah sebanyak 83 orang. Jumlah sampel ditentukan dengan rumus Slovin.

Instrumen pengumpulan data dalam penelitian ini adalah berupa kuesioner tentang tingkat literasi pedagang Pasar Sangkumpal Bonang terhadap produk perbankan syariah . Kuesioner diisi oleh responden (self-administered questionnaire). Selama pengisian kuesioner, penulis mendampingi responden agar ketika terdapat hal yang tidak dipahami oleh responden dapat langsung dijelaskan oleh peneliti. Hal ini dilakukan agar peneliti dapat memperoleh data yang valid.

Pada kuesioner, pertanyaan dijawab dengan menggunakan skala Likert. Skala Likert digunakan untuk mengukur skala yang umum digunakan dalam kuesioner dan merupakan 
skala yang paling banyak digunakan dalam riset berupa survei. Skala Likert yang digunakan dalam penelitian ini adalah skala Likert 5 poin. Skala 1 untuk respon sangat tidak setuju hingga skala 5 respon sangat setuju.

\section{Teknik Analisis Data}

Data yang diperoleh dari hasil penelitian ini dianalisis dengan menggunakan analisis statistik deskriptif dan analisis chi-square. Pertama adalah statistik deskriptif. Statistik deskriptif memberikan gambaran atau deskripsi suatu data yang dilihat dari nilai rata-rata (mean), median, modus, standar deviasi, maksimum dan minimum. Statistik deskriptif merupakan statistik yang menggambarkan atau mendeskripsikan data menjadi sebuah informasi yang lebih jelas dan mudah untuk dipahami. Kedua adalah analisis chi-square.

Statistik deskripif adalah metode statistik yang berusaha menjelaskan atau menggambarkan berbagai karakteristik data. Seperti berapa rata-ratanya, seberapa jauh data-data bervariasi, berapa standar deviasinya, nilai maksimum dan minumum data.

\section{Analisis Chi-Square}

Teknik analisis data dalam penelitian ini menggunakan statistik non-parametrik yakni analisis chi-square. Analisis ini dipilih karena syarat untuk melakukan analisis statistik parametrik tidak terpenuhi. Oleh karena itu, untuk melihat apakah terdapat perbedaan financial literacy pelaku usaha di Pasar Sangkumpal Bonang berdasarkan usia, pendidikan terakhir dan penghasilan rata-rata menggunakan analisis chi-square. Data yang digunakan untuk analisis ini adalah data yang berskala ordinal (literasi keuangan) dan nominal (data usia, pendidikan terakhir dan penghasilan rata-rata).

Dalam menganalisis uji hipotesis menggunakan Chi Square menggunakan keputusan probabilitas, keputusan yang diambil berdasarkan ketentuan berikut. Jika chi-square hitung $<$ chi-square tabel, maka Ho diterima. Dimana,

$\mathrm{H}_{\mathrm{o1}}$ : Tidak terdapat perbedaan sharia financial literacy pedagang di Pasar Sangkumpal Bonang berdasarkan usia.

$\mathrm{H}_{02}$ : Tidak terdapat perbedaan sharia financial literacy pedagang di Pasar Sangkumpal Bonang berdasarkan pendidikan terakhir.

$\mathrm{H}_{03}$ : Tidak terdapat perbedaan sharia financial literacy pedagang di Pasar Sangkumpal Bonang berdasarkan pendapatan (penghasilan rata-rata).

Adapun jika chi-square hitung > chi-square tabel, maka Ho ditolak. Dimana, 
$\mathrm{H}_{\mathrm{a} 1}$ : Terdapat perbedaan sharia financial literacy pedagang di Pasar Sangkumpal Bonang berdasarkan usia.

$\mathrm{H}_{\mathrm{a} 2}$ : Terdapat perbedaan sharia financial literacy pedagang di Pasar Sangkumpal Bonang berdasarkan pendidikan terakhir.

$\mathrm{H}_{\mathrm{a} 3}$ : Terdapat perbedaan sharia financial literacy pedagang di Pasar Sangkumpal Bonang berdasarkan pendapatan (penghasilan rata-rata).

\section{HASIL DAN PEMBAHASAN}

\section{Statistik Deskriptif}

Berdasarkan hasil kuisioner, karakteristik responden berdasarkan usia dapat dilihat pada tabel berikut ini.

Tabel 1. Rekapitulasi Responden Berdasarkan Usia

\begin{tabular}{ccc}
\hline Usia (Tahun) & Jumlah (Orang) & Persentase (\%) \\
\hline 20-30 tahun & 18 & $21,70 \%$ \\
\hline $31-50$ tahun & 34 & $41,00 \%$ \\
\hline >50 tahun & 31 & $37,30 \%$ \\
\hline Total & 83 & $100,00 \%$ \\
\hline
\end{tabular}

Responden kelompok usia 31-50 tahun memiliki jumlah terbesar, yaitu sebanyak 34 orang (41\%). Kemudian disusul kelompok usia lebih dari 50 tahun, yaitu sejumlah 31 orang (37,3\%). Adapun kelompok usia 20-30 tahun hanya berjumlah 18 orang (21,7\%).

Untuk karakteristik responden berdasarkan jenjang pendidikan terakhir dapat dilihat pada tabel berikut ini.

Tabel 2. Rekapitulasi Responden Berdasarkan Pendidikan

\begin{tabular}{ccc}
\hline Pendidikan & Jumlah (Orang) & Persentase (\%) \\
\hline Tidak Lulus SD & 34 & $41,00 \%$ \\
\hline SD-SMA & 25 & $30,10 \%$ \\
\hline >SMA & 24 & $28,90 \%$ \\
\hline Total & 83 & 100,00 \\
\hline
\end{tabular}

Responden kelompok pendidikan tidak lulus Sekolah Dasar memiliki jumlah terbesar, yaitu sebanyak 34 orang (41\%). Kemudian disusul kelompok pendidikan SD-SMA, yaitu sejumlah 25 orang $(30,1 \%)$. Adapun kelompok pendidikan lebih dari SMA menempati posisi terakhir yaitu berjumlah 24 orang $(28,9 \%)$. 
Tabel 3. Rekapitulasi Responden Berdasarkan Pendapatan

\begin{tabular}{ccc}
\hline Pendapatan & Jumlah (Orang) & Persentase (\%) \\
\hline$<5$ juta & 20 & 24,10 \\
\hline 5 -10 juta & 34 & 41,00 \\
\hline$>10$ juta & 29 & 34,90 \\
\hline Total & 83 & 100,00 \\
\hline
\end{tabular}

Responden kelompok pendapatan rata-rata per bulan 5-10 juta rupiah memiliki jumlah terbesar, yaitu sebanyak 34 orang (41\%). Kemudian disusul oleh kelompok pendapatan rata- rata per bulan lebih dari 10 juta rupiah, yaitu sejumlah 29 orang (34,9\%). Adapun kelompok pendapatan rata-rata per bulan kurang dari 5 juta rupiah hanya berjumlah 20 orang $(24,1 \%)$.

\section{Analisis Tingkat Literasi Keuangan Syariah Berdasarkan Usia}

Persentase responden kategori paham keuangan syariah berdasarkan usia dapat dilihat pada Gambar 1 berikut,

Gambar 1. Persentase Responden Kategori Paham Keuangan Syariah

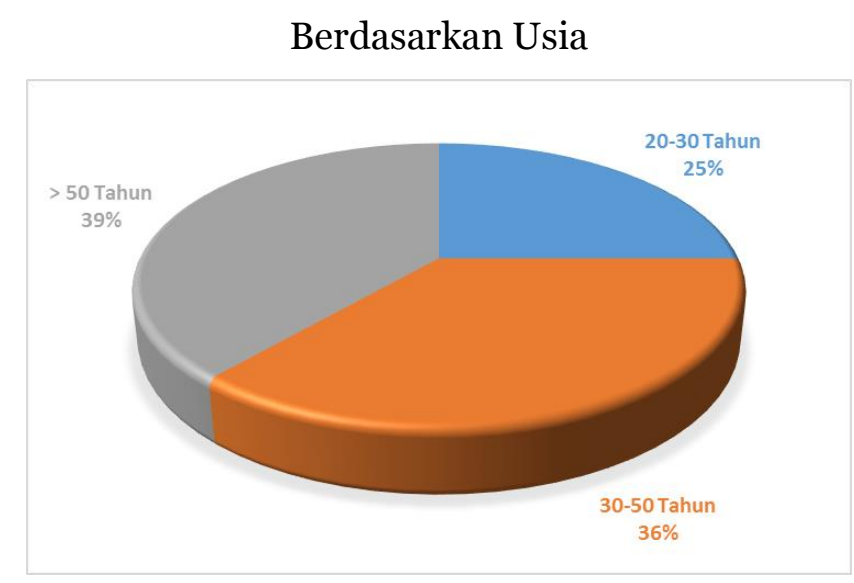

Responden kelompok usia lebih dari 50 tahun merupakan kelompok usia dengan tingkat literasi keuangan syariah tertinggi. Responden sejumlah 17 orang (38,6\% dari seluruh responden yang literated berdasarkan usia) dari kelompok usia tersebut masuk kategori paham keuangan syariah. Peringkat kedua diraih oleh kelompok usia 30-50 tahun, yaitu sebanyak 16 orang (36,4\% dari seluruh responden yang literated berdasarkan usia). Peringkat terakhir adalah kelompok usia 20-30 tahun, yaitu sejumlah 11 orang (25\% dari seluruh responden yang literated berdasarkan usia). 
Gambar 2. Persentase Responden Kategori Buta Keuangan Syariah Berdasarkan Usia

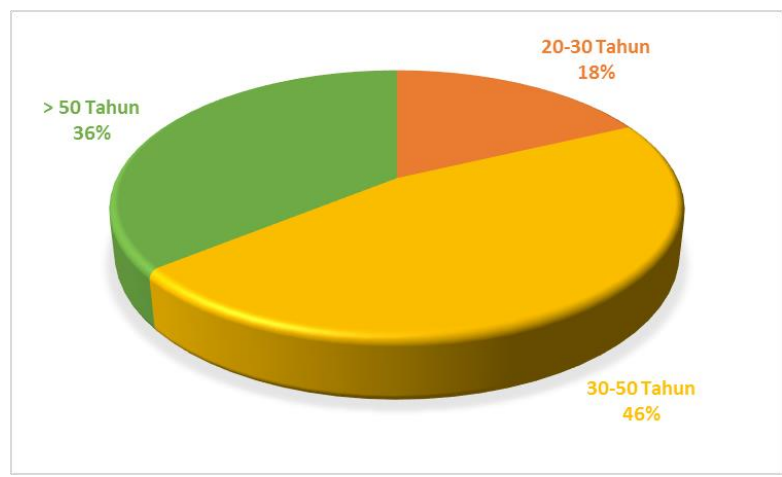

Responden kelompok usia lebih 30-50 tahun merupakan kelompok usia yang paling banyak tidak paham (non-literated) keuangan syariah. Responden sejumlah 18 orang (46,2\% dari seluruh responden yang non-literated berdasarkan usia) kelompok usia tersebut masuk kategori tidak paham keuangan syariah. Peringkat kedua diraih oleh kelompok usia lebih dari 50 tahun, yaitu sebanyak 14 orang (35,9\% dari seluruh responden yang nonliterated berdasarkan usia). Peringkat terakhir adalah kelompok usia 20-30 tahun, yaitu sejumlah 7 orang $(17,9 \%$ dari seluruh responden yang non-literated berdasarkan usia).

\section{Analisis Chi Square Berdasarkan Usia}

Hasil uji Chi-Square Tingkat literasi keuangan syariah berdasarkan usia terhadap 83 orang responden (pedagang pasar sangkumpal bonang) dapat dilihat pada tabel 4.

Tabel 4. Uji Chi Square Berdasarkan Usia

\begin{tabular}{lccc}
\hline & Value & df & $\begin{array}{c}\text { Asymp. Sig } \\
\text { (2-sided) }\end{array}$ \\
\hline Pearson Chi-Square & $.999 \mathrm{a}$ & 2 & 0.607 \\
\hline Likelihood Ratio & 1.003 & 2 & 0.605 \\
\hline $\begin{array}{l}\text { Linear-by-Linear } \\
\text { Association }\end{array}$ & 0.067 & 1 & 0.796 \\
\hline N of Valid Cases & 83 & & \\
\hline
\end{tabular}

Dari tabel chi-square untuk taraf signifikansi 95\% (batas kritis 5\%) pada lampiran diketahui bahwa nilai chi-square tabel adalah sebesar 5,99. Dengan demikian karena 0,999< 5,99 (chi-square hitung < chi-square tabel), maka perbedaan tidak signifikan, artinya terima Ho. Sehingga kita dapat menyimpulkan bahwa tidak terdapat perbedaan sharia financial literacy pedagang di Pasar Sangkumpal Bonang berdasarkan usia. 


\section{Analisis Tingkat Literasi Keuangan Syariah Berdasarkan Pendidikan}

Persentase responden kategori paham keuangan syariah berdasarkan pendidikan dapat dilihat pada Gambar 3 .

Gambar 3. Persentase Kategori Paham Keuangan Syariah Berdasarkan Pendidikan

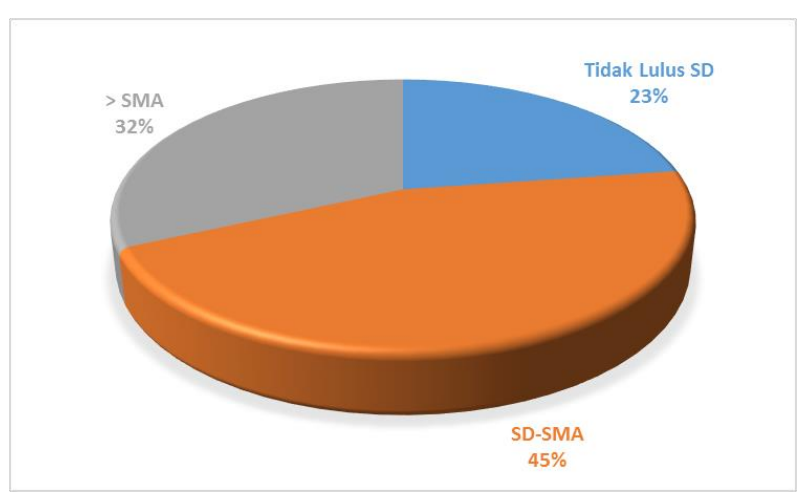

Responden kelompok pendidikan SD-SMA merupakan kelompok tingkat pendidikan responden dengan tingkat literasi keuangan syariah tertinggi. Responden sejumlah 20 orang (45,5\% dari seluruh responden literated berdasarkan pendidikan) masuk kategori paham keuangan syariah. Peringkat kedua diraih oleh kelompok pendidikan lebih dari SMA, yaitu sebanyak 14 orang (31,8\% dari seluruh responden yang literated berdasarkan pendidikan). Peringkat terakhir adalah kelompok pendidikan tidak lulus SD, yaitu sejumlah 10 orang (22,7\% dari seluruh responden yang literated berdasarkan pendidikan terakhir).

Gambar 4. Persentase Responden Berdasarkan Kategori Buta Kueangan Syariah Berdasarkan Pendidikan

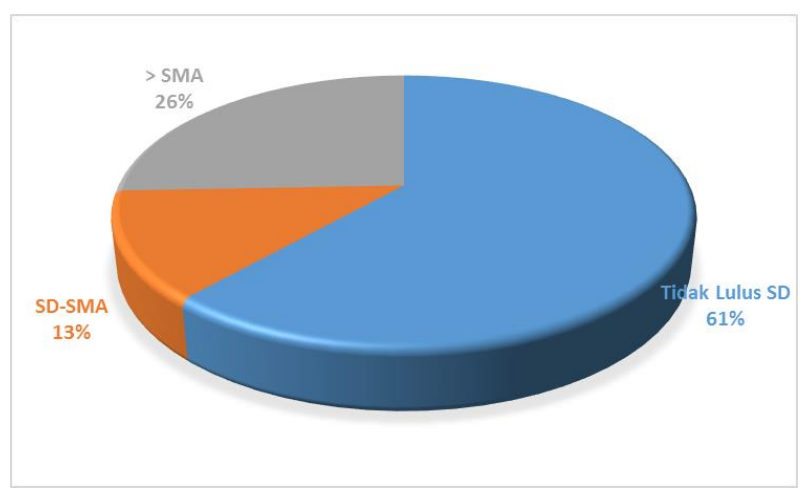

Responden kelompok pendidikan tidak lulus Sekolah Dasar merupakan kelompok pendidikan responden yang paling banyak tidak paham (non-literated) keuangan syariah. Responden sejumlah 24 orang (61,5\% dari seluruh responden yang non-literated berdasarkan pendidikan) masuk kategori tidak paham keuangan syariah. Peringkat kedua diraih oleh kelompok pendidikan lebih dari SMA, yaitu sebanyak 10 orang (25,6\% dari seluruh responden yang non-literated berdasarkan pendidikan). Peringkat terakhir adalah kelompok pendidikan 
SD-SMA, yaitu sejumlah 5 orang $(12,8 \%$ dari seluruh responden yang non-literated berdasarkan pendidikan).

\section{Analisis Chi Square Berdasarkan Pendidikan}

Hasil uji Chi-Square Tingkat literasi keuangan syariah berdasarkan pendidikan terhadap 83 orang responden dapat dilihat pada tabel 5 .

Tabel 5. Hasil Chi-Square berdasarkan Pendidikan

\begin{tabular}{lccc}
\hline & Value & df & $\begin{array}{c}\text { Asymp. Sig. } \\
\text { (2- sided) }\end{array}$ \\
\hline Pearson Chi-Square & $15.185 \mathrm{a}$ & 2 & 0.001 \\
\hline Likelihood Ratio & 15.945 & 2 & 0 \\
\hline $\begin{array}{l}\text { Linear-by-Linear } \\
\text { Association }\end{array}$ & 6.041 & 1 & 0.014 \\
\hline N of Valid Cases & 83 & & \\
\hline
\end{tabular}

Dari tabel chi-square untuk taraf signifikansi 95\% (batas kritis 5\%) pada lampiran diketahui bahwa nilai chi-square tabel adalah sebesar 5,99. Dengan demikian karena 15,185 > 5,99 (chi-square hitung > chi-square tabel), maka perbedaan signifikan, artinya tolak Ho. Sehingga kita dapat menyimpulkan bahwa terdapat perbedaan yang nyata mengenai pemahaman keuangan syariah pedagang pasar sangkumpal bonang dilihat dari tingkat tingkat pendidikan responden.

\section{Analisis Tingkat Literasi Keuangan Syariah Berdasarkan Pendapatan}

Responden kelompok pendapatan lebih dari 10 juta rupiah per bulan merupakan kelompok responden dengan tingkat literasi keuangan syariah tertinggi. Responden sejumlah 20 orang masuk kategori paham keuangan syariah (45,4\% dari seluruh responden paham keuangan syariah - literated - berdasarkan pendapatan rata-rata per bulan). Peringkat kedua diraih oleh kelompok pendapatan 5 - 10 juta rupiah perbulan, yaitu sebanyak 19 orang (43,2\% dari seluruh responden yang literated berdasarkan pendapatan rata-rata per bulan). Peringkat terakhir adalah kelompok pendapatan kurang dari 5 juta rupiah per bulan, yaitu sejumlah 5 orang $(11,4 \%$ dari seluruh responden yang literated berdasarkan pendapatan ratarata per bulan). Persentase responden (pedagang di Pasar Sangkumpal Bonang) kategori paham keuangan syariah (sharia financial literated) berdasarkan pendapatan rata-rata per bulan dapat dilihat pada Gambar 5 . 
Gambar 5. Persentase Kategori Paham Keuangan Syariah Berdasarkan Pendapatan

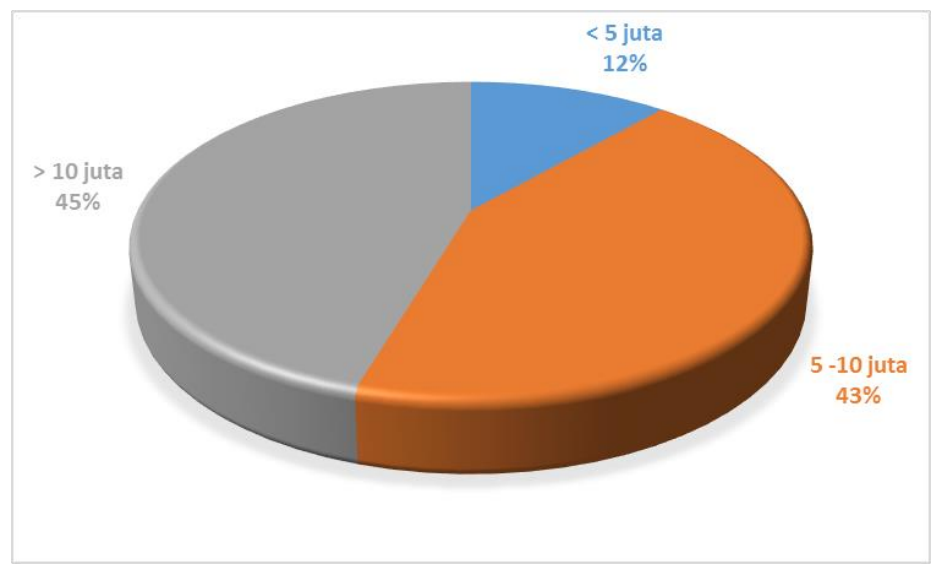

Adapun persentase responden kategori tidak paham (non-literated) keuangan syariah berdasarkan pendapatan rata-rata per bulan dapat dilihat pada Gambar 6.

Gambar 6. Persentase Kategori Buta Keuangan Syariah

Berdasarkan Pendapatan

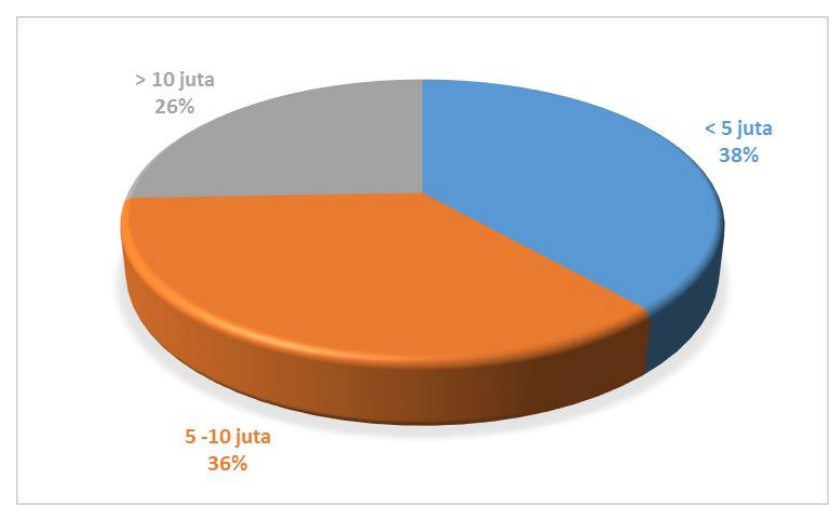

Responden kelompok pendapatan rata-rata kurang dari 5 juta rupiah per bulan merupakan kelompok responden yang paling banyak tidak paham (non-literated) keuangan syariah. Responden sejumlah 15 orang masuk kategori tidak paham keuangan syariah, atau $38,5 \%$ dari seluruh responden yang non-literated berdasarkan pendapatan rata-rata per bulan. Peringkat kedua diraih oleh kelompok pendapatan rata-rata 5-10 juta rupiah per bulan, yaitu sebanyak 14 orang, atau 35,9\% dari seluruh responden yang non-literated berdasarkan pendapatan rata-rata per bulan. Peringkat terakhir adalah kelompok pendapatan rata-rata lebih dari 10 juta rupiah per bulan, yaitu sejumlah 10 orang (25,6\% dari seluruh responden yang non-literated berdasarkan pendapatan rata-rata per bulan). 


\section{Analisis Chi Square}

Hasil uji Chi-Square Tingkat literasi keuangan syariah berdasarkan pendapatan (penghasilan rata-rata per bulan) terhadap 83 orang responden yang merupakan pedagang di pasar sangkumpal bonang, dapat dilihat pada tabel 6.

Tabel 6. Hasil Uji Chi-Square berdasarkan Pendapatan

\begin{tabular}{lccc}
\hline & Value & df & $\begin{array}{c}\text { Asymp. Sig. } \\
\text { (2- sided) }\end{array}$ \\
\hline Pearson Chi-Square & $8.582 a$ & 2 & 0.014 \\
\hline Likelihood Ratio & 8.835 & 2 & 0.012 \\
\hline $\begin{array}{l}\text { Linear-by-Linear } \\
\text { Association }\end{array}$ & 7.034 & 1 & 0.008 \\
\hline N of Valid Cases & 83 & & \\
\hline
\end{tabular}

Dari tabel chi-square untuk taraf signifikansi 95\% (batas kritis 5\%) pada lampiran diketahui bahwa nilai chi-square tabel adalah sebesar 5,99. Dengan demikian karena 8,582 > 5,99 (chi-square hitung > chi-square tabel), maka perbedaan signifikan, artinya tolak Ho. Sehingga kita dapat menyimpulkan bahwa terdapat perbedaan yang nyata mengenai pemahaman keuangan syariah pedagang dilihat dari pendapatan rata-rata per bulan yang dihasilkan oleh responden.

\section{KESIMPULAN}

Hasil kuisioner menunjukkan bahwa responden yang paham mengenai keuangan syariah lebih banyak daripada responden yang tidak paham (non-literated). Responden yang paham (literated) keuangan syariah berjumlah 44 orang (53,01\%), sedangkan responden yang tidak paham (non-literated) keuangan syariah berjumlah 39 orang $(46,99 \%)$.

Penelitian (Uji Khai Kuadrat) ini membuktikan bahwa tidak terdapat perbedaan tingkat literasi keuangan syariah pedagang Pasar Sangkumpal Bonang berdasarkan usia responden. Sedangkan karakteristik responden berdasarkan tingkat pendidikan dan pendapatan menunjukkan perbedaan yang signifikan dalam memahami keuangan syariah. Penelitian ini membuktikan bahwa semakin tinggi tingkat pendidikan responden (pedagang pasar Sangkumpal Bonang), semakin banyak responden yang paham (literated) akan keuangan syariah. Demikian juga halnya tingkat pendapatan responden, semakin tinggi pendapatan rata-rata per bulan, semakin banyak pula responden yang literated keuangan syariah. 


\section{DAFTAR PUSTAKA}

Cole, Shawn, Thomas Sampson, dan Bilal Zia. 2009. "Financial Literacy, Financial Decisions, and the Demand for Financial Services: Evidence from India and Indonesia". Harvard Business School Working Paper. Vol. 09. Hal.117.

Departemen Agama RI. 2005. Al-Quran dan Terjemahan. Jakarta: CV. Penerbit J-Art.

Hall, Keith. The Importance Of Financial Literacy disampaikan pada Conference on Deepening Financial Capacity in the Pacific Region, Sydney, 25 Augustus 2008.

Hasibuan, Melayu SP. 2009. Dasar-dasar Perbankan. Jakarta: PT. Bumi Aksara.

Hasyim, Musyafiq dan Abdullah Salam. 2015. "Analisis Pengaruh Pendidikan Dan Pekerjaan Terhadap Pengetahuan Produk Perbankan Syari'ah (Studi Kasus Kepala Keluarga di Dukuh Krapyak Kulon, Panggungharjo, Sewon, Bantul, Yogyakarta Tahun 2013)”. Jurnal Ekonomi Syariah Indonesia. Vol. 5 No.1.

Hidayat, Sutan Emir. 2015. "Meningkatkan Preferensi Publik terhadap Keuangan Syariah". Iqtishodia: Jurnal Ekonomi Islam Republika.

Huston, S. J. 2010. "Measuring Financial Literacy". The Journal of Consumer Affairs. Vol. 44 No.2.

Ismail. 2011. Perbankan Syariah. Jakarta: Kencana.

Karim, Adiwarman A. 2010. Bank Islam Analisis Fiqh dan Keuangan. Jakarta: Rajagrafindo Persada.

Kasmir. 2004. Manajemen Perbankan. Jakarta: PT.RajaGrafindo Persada.

Lusimbo, N. E. dan W. Muturi. 2003. "Financial Literacy and The Growth of Small Enterprises in Kenya: A Case of Kakamega Central Sub-Country, Kenya”. International Journal of Economics, Commerce and Management. Vol.4 No.2. Hal. 828-845.

Morissan, dkk. 2012. Metode Penelitian Survei. Jakarta: Kencana Prenada Media Group.

Muflihani, Zara Fathia. 2015. "Tingkat Literasi Pelaku Usaha Mikro terhadap Perbankan Syariah”. Iqtishodia: Jurnal Ekonomi Islam Republika.

Muhammad. 2008. Metodologi Penelitian Ekonomi Islam. Jakarta: Rajawali Pers.

Oseifuah, Emmanuel K. 2010. "Financial Literacy and Youth Entrepreneurship in South Africa, African”. Journal of Economic and Management Studies. Vol. 1 No. 2.

Otoritas Jasa Keuangan. 2013. Edukasi dan Perlindungan Konsumen diakses melalui situs: http://www.ojk.go.id/id/kanal/edukasi-dan-perlindungankonsumen/Pages/Literasi-Keuangan.aspx tanggal 2 Januari 2018.

Otoritas Jasa Keuangan. 2016. Industri Jasa Keuangan Syariah. Jakarta: Otoritas Jasa Keuangan.

Perwataatmadja, Karnaen dan Muhammad Syafi'i Antonio. 1992. Apa Dan Bagaimana Bank Islam. Yogyakarta: Dana Bhakti Wakaf.

Priyanto, Dwi. 2014. SPSS 22 Pengolahan Data Terpraktis. Yogjakarta: Andi.

Remund, D. L. 2010. "Financial Literacy Explicated: The Case for a Cleaner Definition in an Increasingly Complex Economy". The Journal of Consumer Affairs. Vol. 44 No. 2.

Sugiyono. 2012. Metode Penelitian Bisnis. Bandung: Alfabeta.

Sumitra, Warkum. 1996. Azas-Azas Perbankan Islam dan Lembaga Terkait (BMUI dan Takaful) di Indonesia. Jakarta: Raja Grafindo Persada.

Suwiknyo, Dwi. 2009. Kamus Lengkap Ekonomi Islam. Jakarta: Total Media.

Widayani, Irin. 2010. "Faktor-faktor yang mempengaruhi Literasi Finansial Mahasiswa Fakultas Ekonomi dan Bisnis Universitas Brawijaya”. ASSET : Jurnal Akuntansi dan Pendidikan. Volume 1. Nomor 1.

Zulkifli, Sunarto. 2003. Panduan Praktis Transaksi Perbankan Syariah. Jakarta: Zikrul Hakim. 